\title{
Caminhando sobre fronteiras: o papel da educação na vida de adultos migrantes
}

\author{
Fernando Frochtengarten \\ São Paulo: Summus Editorial, 2009, 169p.
}

Este livro tem como tema de fundo o relato da experiência de uma relação vivenciada na educação de jovens adultos em sua condição de migrantes de origem rural na cidade de São Paulo. Originalmente esse trabalho foi apresentado como tese de doutoramento em Psicologia Social pelo Instituto de Psicologia da Universidade de São Paulo. Porém seu escopo vai além desse enquadramento acadêmico, pois se trata de uma reflexão que se embasa em uma experiência real, vivida cotidianamente em sala de aula e nos espaços do Colégio Santa Cruz, na zona oeste da cidade, onde o autor exerceu sua função de professor nas aulas noturnas do supletivo frequentadas pelos migrantes estudantes. A partir dessa experiência, o autor inicia uma trajetória em que se articulam o relato do vivido em seus relacionamentos com "a reflexão disciplinada sobre os diversos lugares ocupados pela escola ao longo da história de vida" (p. 21) de um grupo determinado de estudantes migrantes, originários de uma mesma região, entre Minas Gerais e Bahia.

O livro está estruturado em quatro capítulos, procurando dar conta desta "caminhada entre fronteiras", realizada por um professor paulistano que busca compreender o papel da educação na transformação das representações e modos de vida desses alunos migrantes. Sua metodologia passa por uma exploração de suas interações com seus alunos, servindo-se de recursos que, ao mesmo tempo em que garantem o grau de confiança adquirido em sala de aula e na convivência cotidiana, possibilitem também um distanciamento imprescindível para a análise. Dessa forma, o que se busca é o emprego de um olhar crítico, seja para com sua posição de professor não-migrante, seja para com a condição social do grupo de estudantes migrantes pesquisado. Podemos resumir então os recursos empregados basicamente em três: o método dos "grupos focais", que o autor adapta às suas circunstâncias de pesquisa como "grupos de conversa"; as entrevistas individuais; e a "observação participante", sob duas modalidades, através da observação de seu cotidiano na escola, nas interações em sala de aula como em outros ambientes do colégio, e através de uma viagem às regiões de 
origem dos estudantes, em que pôde observar o que seria o ciclo completo da vida dos alunos. Esses procedimentos metodológicos, sobretudo sua viagem à região de origem dos alunos, deram à pesquisa a grande virtude de recuperar a inteireza da condição social desses migrantes, bem como uma compreensão mais completa de sua experiência escolar, as razões de suas lacunas e de sua revalorização no espaço urbano.

Ao longo dos capítulos, a trajetória da pesquisa traduz o objetivo que o autor se propõe: contribuir para a "compreensão da identidade do aluno adulto e para a reflexão sobre as ações do educador" (p. 23). No primeiro capítulo, apresenta-se um perfil dos alunos que frequentam o supletivo noturno do Colégio Santa Cruz, suas características sociais, e o modo como se relacionam em sala de aula e com os espaços e equipamentos do colégio. Também o autor faz uma explanação do objetivo da educação diante dessa população, os desafios que o "letramento" apresenta para esses estudantes, deixando claro que adota a perspectiva de Paulo Freire, na "Pedagogia do Oprimido" (p. 4345). O autor também expõe a linha de procedimento metodológico, em que se destaca a viagem aos lugares de origem de seus alunos, cujo objetivo seria fazer a observação etnográfica na linha preconizada por Geertz. O segundo capítulo traz a riqueza dessas observações coletadas em seu diário de campo, e devidamente comentadas tornam essas páginas talvez as mais interessantes de todo livro. Isso devido ao fato, como o próprio autor reconhece, dessa experiência inverter a relação "nativo-estranho", na medida em que o professor se torna estrangeiro nos lugares de origem de seus estudantes, que por sua vez surgem como os nativos "estrangeirizados" pela migração, prontos e adaptados a fazer o autor conhecer sua realidade de origem. Esse deslocamento feito pelo professor produz uma ação de desvendamento das razões da evasão escolar em meio rural, do reconhecimento do "letramento" como tipicamente urbano, das razões econômicas e culturais da migração, tornando-a uma verdadeira "tradição" através de suas redes sociais (p.83-88). É através dessa experiência que o autor pode afirmar que "o fenômeno migratório que concentrava inúmeros conterrâneos no supletivo era, paradoxalmente, a razão para que muitos deles não se conhecessem. A vida deles transcorria como fragmentos resultantes da detonação do chão sertanejo" (p. 88).

Os dois últimos capítulos, como retorno ao ambiente escolar, permitem ao autor fazer sua análise sobre o papel da educação na vida de trabalhadores migrantes no espaço urbano. A recuperação da inteireza da experiência migratória e escolar dos seus alunos através das observações em sua viagem ao sertão e, sobretudo, o seu próprio deslocamento, como experiência migratória ao avesso, mesmo que muito provisória, criou a possibilidade de um novo olhar sobre o papel da escola, do espaço urbano e da condição de migrantes na trajetória de vida de seus alunos. São elementos que podem ajudar a pensar de 
uma nova forma a prática pedagógica com adultos: "o papel potencialmente assumido por uma escola para a participação das subjetividades migrantes e sertanejas na sociedade urbana" (p. 111). Inicialmente, o autor explora esses elementos a partir de sua própria experiência de professor de ciências naturais, que confronta o modo de relacionamento com a natureza no mundo rural, trazido por seus alunos, com aquele desenvolvido no meio urbano. A escola, quando aberta aos saberes que os migrantes trazem de sua vivência rural, torna-se o terreno fecundo de um "confronto cultural", de uma dialética que permeia a vida de cada estudante: de um lado traz elementos da cultura sertaneja para a escola; de outro, é o portador de uma "visita dos saberes escolares ao sertão" (p. 126). A escola se torna o caminho de um novo enraizamento no meio urbano, abrindo outras possibilidades de reconhecimento e participação social. Nesse sentido, o autor fala das "identidades de fronteira" desenvolvidas pelos alunos na sua interação com o ambiente escolar e com outros alunos de igual condição social. Criam a consciência de um duplo pertencimento, em que se assimilam e dialogam referências do meio de origem e do meio urbano.

No quarto capítulo, o autor explora justamente como toda essa experiência incide nos projetos de futuro dos alunos. Na verdade, a escola é uma experiência complementar a todo projeto migratório que os trouxe à cidade. Inicialmente a volta do adulto de origem rural à escola é uma nova fronteira na sua busca para criar meios para uma melhora de condição de vida, e mesmo de uma sonhada ascensão social. Depois, progressivamente, a escola vai abrindo outras possibilidades de contato com a mentalidade e os espaços do mundo urbano, gerando outras transformações, no modo de falar, de pensar, de agir, no andar, nos relacionamentos diários. A introdução no mundo letrado permite um ganho na autoestima de cada um, bem como na descoberta de outra face da cidade: não apenas como lugar do trabalho anônimo e subalterno, mas como um espaço e um bem que podem ser usufruídos. Se a escola em geral influenciou timidamente na ascensão social desses estudantes e trabalhadores, ela porém ajudou em muito a que eles tivessem uma nova visão de si mesmos e de seu lugar social. Isso é bem mais perceptível naqueles que, deixando a escola, retornaram ao seu meio de origem. Aqueles que não abriram negócios nos núcleos urbanos das suas cidades, mas se dirigiram ao meio rural, mudaram qualitativamente sua posição frente aos seus pares, tornando-se agentes de saúde ou professores. O olhar urbanizado e escolarizado sobre o sertão fez com que, voltando, não fossem mais os mesmos, mas agissem de outra forma sobre suas condições originais de vida.

$\mathrm{O}$ autor termina lembrando a condição de provisoriedade permanente do migrante, que na verdade parece ser a de todo homem contemporâneo: a "opacidade do futuro é agravada pela instabilidade dos esquemas de vida dos alunos, a começar pelo desconhecimento do lugar aonde a vida vai desenrolar-se. 
A retração do horizonte ao momento atual traz implicações para a educação" (p.154). O autor descobre, confrontando-se com os migrantes, participando da mesma dialética experimentada por seus alunos, que ele próprio é um "migrante" apesar de ser um legítimo paulistano morando em São Paulo, percebendo a ilusão de solidez de sua condição de vida, em aprendizado constante.

Temos assim diante de nós um livro extremamente agradável de ler e que apresenta um respeito e uma empatia raramente vistas em relação à condição vivida pelos migrantes. Nos caminhos abertos por Paulo Freire, o autor avança a reflexão no sentido de apontar elementos importantes para práticas pedagógicas que dialoguem com os adultos migrantes, valorizando a inteireza de sua experiência de vida. Mais do que isso, lembra e reforça o papel da educação como meio de transformação social, desde que possa restituir àqueles que se encontram na posição de estudantes, no caso os migrantes de origem rural, o seu lugar de protagonistas dessa mesma transformação. Nesse sentido, é um livro que transborda esperança, iluminado pela consciência de uma igualdade fundamental entre estudantes e professores, todos carregados de conhecimentos a serem partilhados, prenhes do desejo de fazer novas descobertas. Afinal somos todos, como bem lembra o autor, Homo sapiens sapiens.

Sidnei Marco Dornelas Centro de Estudos Migratórios 